\title{
CrimRxiv
}

\section{PUBLIC SAFETY TRENDS IN MAP COMMUNITIES AND MATCHED COMPARISON AREAS}

John Jay Research and Evaluation Center

Published on: May 10, 2019

DOI: 10.21428/cb6ab371.dbf92b31

License: Creative Commons Attribution 4.0 International License (CC-BY 4.0). 
